\title{
Vitrification of Simulated Fernald K-65 Silo Waste at Low
}

Temperature

$$
\text { CONF-980521-- }
$$

by

C. M. Jantzen

Westinghouse Savannah River Company

Savannah River Site

Aiken, South Carolina 29808

J. B. Pickett

A document prepared for 100TH ANNUAL MEETING OF THE AMERICAN CERAMIC SOCIETY at Cincinnati, $\mathrm{OH}$, USA from $5 / 3 / 98-5 / 6 / 98$.

DOE Contract No. DE-AC09-96SR18500

This paper was prepared in connection with work done under the above contract number with the U.S. Department of Energy. By acceptance of this paper, the publisher and/or recipient acknowledges the U. S. Government's right to retain a nonexclusive, royalty-free license in and to any copyright covering this paper, along with the right to reproduce and to authorize others to reproduce all or part of the copyrighted paper. 
WSRC-MS-97-00854, Revision 1

\section{VITRIFICATION OF SIMULATED FERNALD K-65 SILO WASTE AT LOW TEMPERATURE (U)}

C. M. Jantzen and J. B. Pickett

Westinghouse Savannah River Company

Aiken, SC 29008

and

R.S. Richards

Associated Technical Consultants

P.O. Box 352393

Toledo, Ohio 43635-2393

A paper for presentation at the 100th American Ceramic Society Annual Meeting in Cincinnati, Ohio, May 3-6, 1998 and for publication in the Symposium on Waste Management Technologies in Ceramic and Nuclear Industries. 


\title{
VITRIFICATION OF SIMULATED FERNALD K-65 SILO WASTE AT LOW TEMPERATURE
}

\author{
C. M. Jantzen, $\dagger$ J.B. Pickett, ${ }^{\dagger}$ and R. S. Richards * \\ $\dagger$ Westinghouse Savannah River Co. \\ Savannah River Site \\ Aiken, South Carolina 29808 \\ * Associated Technical Consultants \\ P.O. Box 352393 \\ Toledo, Ohio 43635-2393
}

\begin{abstract}
Vitrification is one of the technologies that has been chosen to solidify $\sim 18,000$ tons of geologic mill tailings, designated as K-65 wastes, at the Fernald Environmental Management Project (FEMP) in Fernald, Ohio. The glass formula developed in this study for the FEMP wastes is a lithia substituted soda-limelithia-silica (SLLS) composition which melts at $1050^{\circ} \mathrm{C}^{1}$. Low melting formulations minimize volatilization of hazardous species such as arsenic, selenium, chromium, and lead during vitrification. Formulation in the SLLS system avoids problematic phase separation known to occur in the $\mathrm{MO}-\mathrm{B}_{2} \mathrm{O}_{3}$ $\mathrm{SiO}_{2}$ glass forming system (where $\mathrm{MO}=\mathrm{CaO}, \mathrm{MgO}, \mathrm{BaO}$, and $\mathrm{PbO}$ which are all constituents of the FEMP wastes). The SLLS glass passed the Environmental Protection Agency (EPA) Toxic Characteristic Leach Procedure (TCLP) for all the hazardous constituents of concern under the previous characteristically waste regulations. The SLLS glass is as durable as high melting soda-lime-silica glasses and is more durable than the borosilicate glasses previously developed for the K-65 wastes. Optimization of glass formulations in the SLLS glass forming system should provide glasses which will pass the newly promulgated Universal Treatment Standards (UTS) which take effect on August 28, 1998.
\end{abstract}

\section{INTRODUCTION}

Vitrification is one of the technologies that has been chosen to solidify geological mill tailings at the FEMP facility in Fernald, Ohio. The geologic mill tailings are residues from the processing of pitchlende ores during 1949-1958. These residues are contained in silos in Operable Unit 4 (OU4) at the FEMP facility. OU4 is one of five operable units at the FEMP. OU4 consists of four concrete storage silos

1 patent pending on SRTC Lithia Additive Melting Process (LAMP ${ }^{\text {MM }}$ ) technology 
and their contents. Silos 1 and 2 contain K-65 mill tailing residues, Silo 3 contains non-radioactive metal oxides, and Silo 4 is empty. The 14,262 tons (12.9 million kilograms) of K-65 residues contain radium ( $\left.\mathrm{Ra}^{226}\right)$, uranium $\left(\mathrm{U}^{234,235,236,238}\right)$, uranium daughter products $\left(\mathrm{Th}^{230}\right)$, and heavy metals such as lead and barium plus 1,185 tons of bentonite which was added to the silo headspace in 1991 to lower the radon concentration in the silo domes in 1991 [1].

Vitrification was chosen as the preferred technology for the Silo 1, 2, and 3 wastes [1,2]. Glasses that melted at high temperatures $\left(1289-1595^{\circ} \mathrm{C}\right)$ were developed by Pacific Northwest National Laboratory (PNNL) [1,2] and glasses that melted at lower temperatures $\left(1150-1350^{\circ} \mathrm{C}\right)$ were developed by the Vitreous State Laboratory (VSL) for the K-65 silo wastes. The PNNL formulated glasses primarily in the soda-lime-silica (SLS) system since the waste is high in $\mathrm{BaO}$ which readily substitutes for $\mathrm{CaO}$ (lime) in SLS glass. The VSL formulated glasses primarily in the borosilicate glass forming system. The PNNL and the VSL conducted both crucible and pilot scale vitrification studies.

A Vitrification Pilot Plant (VPP) was constructed at FEMP to operate at temperatures up to $1450^{\circ} \mathrm{C}$. The VPP began operation at FEMP on June 19, 1996. During the initial startup testing, 12.5 tons of benign startup "frit" were melted. Silo 1, 2, and 3 surrogate melter tests were completed in September 1996 and produced 11 tons of glass. Another campaign using Silor 1 and 2 surrogate with bentonite was subsequently performed. All of the VPP surrogate testing was completed at melt temperatures between $1130^{\circ} \mathrm{C}$ and $1350^{\circ} \mathrm{C}$. A final transition to lower temperature operation at $\sim 150^{\circ} \mathrm{C}$ was planned when the VPP failed on December 26, 1996.

This study documents SRTC glass formulation and development for K-65 waste that was completed in April, 1993. The SLS based glass developed in this study takes advantage of the glass forming ability of the waste, e.g. has an $84 \%$ waste loading and a volume reduction of $\sim 60 \%$, but melts at $1050^{\circ} \mathrm{C}$. The low vitrification temperature minimizes volatilization of the RCRA hazardous constituents (As, $\mathrm{Pb}, \mathrm{Se}, \mathrm{Cr}$ ) and minimizes corrosion of melter materials of construction.

\section{BACKGROUND}

In 1991 PNNL analyzed the composition of K-65 residues from Fernald on a dry wt\% calcine (oxide) basis [1]. The waste analyses were comparable to (a) analyses performed by Controls for Environmental Pollution, Inc. (CEP) in 1990 and (b) analyses performed by National Lead of Ohio (NLO) prior to 1989 [1]. In 1993, PNNL published [2] an average composition for the K-65 residues in Silos 1 and 2, an average composition of the Silo 3 waste, and an average composition for the BentoGrout ${ }^{\mathrm{TM}}$ added to the tank headspace (Table I). Note that the PNNL analyses are normalized and contain significant contributions of unspecified components designated as "other." The K-65 Silo 1 and 2 residues 
were reported to contain between 1-3 wt\% sulfate and the Silo 3 material is reported to contain up to $18 \mathrm{wt} \%$ sulfate on a dry solids basis [2].

Analyses performed by FEMP in 1993 indicate that the sulfate in Silo 1 varies between 0.04 and $0.35 \mathrm{wt} \%$ on a wet solids basis while the sulfate in Silo 2 varies between $0.26-1.93$ wt\% on a wet basis [3]. The total organic carbon (TOC) for Silo 1 wastes varies from 0.52 to $3.48 \mathrm{wt} \%$ on a wet basis while the TOC for Silo 2 varies from 0.01 to $2.44 \mathrm{wt} \%$ on a wet solids basis [3]. In February, 1998 FEMP developed revised surrogate waste compositions for Silo 1 and 2 wastes and BentoGrout ${ }^{\mathrm{TM}}$ [3]. For comparison, the 1993 PNNL average compositions are compared to the 1998 FEMP surrogate waste compositions in Table I.

Due to the high concentrations of silica $\left(\mathrm{SiO}_{2}\right)$, lime $(\mathrm{CaO})$, baria $(\mathrm{BaO})$, and $\mathrm{PbO}$ in the K-65 Fernald wastes, PNNL chose the use of soda-lime-silica (SLS) glass for solidification [1,2]. PNNL only formulated glasses in the borosilicate system for Silo 3 wastes which contained no PbO. For the K-65 wastes, the initial PNNL formulations required only one simple additive, $\mathrm{Na}_{2} \mathrm{O}$ as $\mathrm{NaOH}$ or $\mathrm{Na}_{2} \mathrm{CO}_{3}$, rather than formulation of a complex glass making frit.

Table I. Chemical Analyses and Oxide Surrogates for K-65 Residues (Silos 1 and 2), Silo 3 FEMP Wastes, and BentoGrout ${ }^{\mathrm{TM}}$

\begin{tabular}{|c|c|c|c|c|c|c|}
\hline & $\begin{array}{c}1993 \\
\text { Average } \\
\text { K-65 Silos } \\
1 \& 2 \\
{[2]} \\
\end{array}$ & $\begin{array}{c}\text { K65 Silo 1 } \\
\text { Surrogate } \\
\text { with } 9 \text { wt } \% \\
\text { Bento- } \\
\text { Grout }^{\mathrm{TM} *} \\
{[4]} \\
\end{array}$ & $\begin{array}{c}\text { K65 Silo } 2 \\
\text { Surrogate } \\
\text { with } 9 \text { wt } \% \\
\text { Bento- } \\
\text { Grout }^{\mathrm{TM} *} \\
{[4]} \\
\end{array}$ & $\begin{array}{c}1993 \\
\text { FEMP } \\
\text { Silo } 3 \\
\\
\\
{[2]} \\
\end{array}$ & $\begin{array}{c}1993 \\
\text { Bento- } \\
\text { Grout }^{\mathrm{TM}}\end{array}$ & $\begin{array}{c}1998 \\
\text { Bento- } \\
\text { Grout }^{\mathrm{TM}} \\
\\
{[4]} \\
\end{array}$ \\
\hline $\mathrm{Al}_{2} \mathrm{O}_{3}$ & 3.7 & 4.77 & 5.77 & 8.3 & 15.8 & 16.27 \\
\hline $\mathrm{BaO}$ & 6.3 & 6.32 & 3.48 & 0.1 & -- & -- \\
\hline $\mathrm{CaO}$ & 1.5 & 0.18 & 3.73 & 7.3 & 1.8 & 1.85 \\
\hline $\mathrm{Fe}_{2} \mathrm{O}_{3}$ & 4.8 & 3.56 & 6.69 & 12.6 & 3.6 & 3.71 \\
\hline $\mathrm{K}_{2} \mathrm{O}$ & 0.9 & 0.81 & 1.50 & 2.8 & 0.8 & 0.82 \\
\hline $\mathrm{MgO}$ & 1.7 & 2.18 & 2.11 & 15.8 & 6.3 & 6.49 \\
\hline $\mathrm{Na}_{2} \mathrm{O}$ & 1.7 & 1.41 & 1.34 & 9.3 & 3.4 & 3.50 \\
\hline $\mathrm{P}_{2} \mathrm{O}_{5}$ & 0.8 & 0.58 & 0.68 & 14.5 & 1.4 & --- \\
\hline $\mathrm{PbO}$ & 12.3 & 13.81 & 6.92 & 0.3 & -.- & $\ldots$ \\
\hline $\mathrm{SiO}_{2}$ & 62.9 & 62.08 & 62.38 & 22.0 & 65.4 & 67.35 \\
\hline $\mathrm{SO}_{4}$ & -- & 4.30 & 5.41 &.- & -- & -- \\
\hline Other & 3.5 & --- & --- & 7.2 & 1.5 & -- \\
\hline SUM & 100.00 & 100.0 & 100.0 & 100.0 & 100.0 & 100.0 \\
\hline
\end{tabular}

*2-3 grams kerosene added to the surrogate to simulate the Total Organic Carbon 
PNNL developed four series of glass compositions for various combinations of actual FEMP wastes [1, 2]. Series A glass was a SLS formulation containing 88$89 \mathrm{wt} \% \mathrm{~K}-65$ waste and 11-12 wt $\% \mathrm{Na}_{2} \mathrm{O}$ glass formers. Series B glass was an SLS formulation containing equal amounts of $\sim 45 \% \mathrm{~K}-65$ and $\sim 45 \%$ BentoGrout ${ }^{\mathrm{TM}}$. Series $\mathrm{C}$ glass was a borosilicate formulation containing $\sim 74 \%$ Silo 3 waste. Series D glass was an SLS formulation containing $\sim 37 \%$ K-65 and $\sim 37 \%$ Silo 3 wastes. Carbon was added to PNNL-A, B and D melts to reduce the sulfate $\left(\mathrm{SO}_{4}\right)$ to $\mathrm{SO}_{3}$ or $\mathrm{SO}_{2}$ vapor [2]. However, the final glass redox was not measured and several of the glasses exhibited the formation of metallic nodules indicating that too much reduction had occurred in the glass causing sulfides and metallic species to form. For the Series D glasses even significant quantities of carbon ( $9 \mathrm{~g}$ of carbon $100 \mathrm{~g}$ of glass) did not mitigate sulfate formation on the melt surface.

All of the PNNL glasses contained between $74-89$ wt $\%$ waste on a dry oxide basis which corresponded to volume reductions of $50-68 \%[1,2]$. All of the PNNL glasses melted at elevated temperatures between $1289^{\circ}$ and $1595^{\circ} \mathrm{C}$. Glasses PNNL-A, C and D contained unidentified white crystalline inclusions while PNNL-C (a borosilicate glass) and PNNL-D (a high sulfate containing glass) were reported to be potentially phase separated.

The Vitreous State Laboratory (VSL) formulated K-65 waste glasses in the sodium-borosilicate (SBS) ${ }^{2}$ system at various boron concentrations (5.88-12.8 wt $\%$ ). During minimelter tests, urea was added to control foaming attributed to sulfate volatilization. These SBS glasses had waste loadings varying between 60 $74 \mathrm{wt} \%$ and melted at temperatures between $1000-1050^{\circ} \mathrm{C}$.

The $\mathrm{K}-65$ Silo 1 and 2 wastes contain 7-12.3 wt $\% \mathrm{PbO}$, 3.5-6.3 wt $\% \mathrm{BaO}, 0.2-$ $3.7 \mathrm{wt} \% \mathrm{CaO}$, and 1.7 to $2.2 \mathrm{wt} \% \mathrm{MgO}$ (Table I). The $\mathrm{PbO}-\mathrm{SiO}_{2}-\mathrm{B}_{2} \mathrm{O}_{3}, \mathrm{BaO}-$ $\mathrm{SiO}_{2}-\mathrm{B}_{2} \mathrm{O}_{3}, \mathrm{CaO}-\mathrm{SiO}_{2}-\mathrm{B}_{2} \mathrm{O}_{3}$, and $\mathrm{MgO}-\mathrm{SiO}_{2}-\mathrm{B}_{2} \mathrm{O}_{3}$ glass forming systems all contain large regions of phase separation [5]. At concentrations greater than 40 wt\% $\mathrm{SiO}_{2}$, the phase separation is metastable in the $\mathrm{PbO}-\mathrm{SiO}_{2}-\mathrm{B}_{2} \mathrm{O}_{3}$ system [6] and causes the separation of an $\mathrm{SiO}_{2}$ rich glass from a much denser $\mathrm{PbO} \cdot 2 \mathrm{~B}_{2} \mathrm{O}_{3}$ rich glass [6]. Therefore, formulation of borosilicate waste glasses for the K-65 wastes may readily produce phase separated glasses, as observed in the PNNL-C series glasses, with the $\mathrm{PbO}$ being stabilized in a borate rich phase. The borate rich phase, being more soluble than the silica rich phase, would be prone to release more $\mathrm{Pb}$ than a homogeneous glass during durability testing.

The low melting borosilicate glasses developed by the VSL and those subsequently developed by FEMP had total $\mathrm{MO}$ (where $\mathrm{MO}=\mathrm{PbO}, \mathrm{BaO}, \mathrm{CaO}$ and $\mathrm{MgO}$ ) concentrations within the known regions of phase separation in the $\mathrm{PbO}-\mathrm{SiO}_{2}-\mathrm{B}_{2} \mathrm{O}_{3}$ and $\mathrm{BaO}-\mathrm{SiO}_{2}-\mathrm{B}_{2} \mathrm{O}_{3}, \mathrm{CaO}-\mathrm{SiO}_{2}-\mathrm{B}_{2} \mathrm{O}_{3}$, and $\mathrm{MgO}-\mathrm{SiO}_{2}-\mathrm{B}_{2} \mathrm{O}_{3}$ systems [7].

${ }^{2}$ This report distinguishes between borosilicate and soda-lime-silic (SLS) based on the ASTM C162 definition of borosilicate glass containing $>5 \mathrm{wt} \% \mathrm{~B}_{2} \mathrm{O}_{3}$. 


\section{MAY 1998 ENVIRONMENTAL PROTECTION AGENCY (EPA) REGULATIONS}

The K-65 Silo 1 and 2 wastes are a characteristically hazardous waste, as they leach lead at a rate greater than 100 times [1] the allowable Environmental Protection Agency (EPA) Resource, Concentration, and Recovery Act (RCRA) concentration limits [8], (the limits given in Table II, Column A). Therefore, the K-65 Silo 1 and 2 wastes are RCRA hazardous and radioactive (mixed) wastes. The Silo 3 wastes are a dry powdery mixture of metal oxides with a much lower concentration of radionuclides (thorium, uranium and $\mathrm{Pb}^{210}$ ) than the Silo 1 and 2 wastes. There are approximately 4000 tons of Silo 3 wastes for disposal. The Silo 3 wastes leach arsenic, chromium, cadmium, and selenium at concentrations exceeding characteristically hazardous RCRA limits. Therefore, the K-65 Silo 3 wastes are also RCRA characteristically hazardous and radioactive (mixed) wastes.

Prior to August, 1998, the FEMP wastes would have had to be treated to meet the EPA Characteristically Hazardous Limits given in Table II, Column A. However in August, 1995, the EPA proposed a new rule (Phase IV of the Land Disposal Restrictions) which would require Characteristically Hazardous Waste to be treated to the same Universal Treatment Standards (UTS) as those for listed mixed wastes [9]. The Phase IV Rule was finalized on May 26, 1998, and will take affect August 26, 1998 [10]. Any mixed wastes not stabilized by that date will be required to be treated to the UTS limits, rather than to the Characteristically Hazardous Limits shown in Table II. The final Phase IV UTS limits for the RCRA metals are given in Table II, Column B. This lowers the acceptable Pb TCLP concentration for K-65 waste forms from the previous $5 \mathrm{mg} / \mathrm{L}$ to 0.75 $\mathrm{mg} / \mathrm{L}$.

The final rule requires that a treated waste form be tested against the UTS standards not only for the constituents which fail the TCLP characteristically hazardous limit, but for all "hazardous constituents which are present in the waste, i.e., underlying hazardous constituents" [10]. The Fernald Silo 1 and 2 wastes exhibit TCLP leaching concentrations for lead which exceed the Toxicity Limit, and leachant levels for nickel (Ni) and selenium (Se) which exceed the UTS in some of the analysis. Therefore, under the final regulations the final waste form will have to meet the UTS for lead, and probably for $\mathrm{Ni}$ and Se, as given in Table II, Column B. Similarly, the Silo 3 wastes contain $\mathrm{As}, \mathrm{Cd}, \mathrm{Cr}, \mathrm{Pb}$, and $\mathrm{Se}$ as underlying hazardous constituents. The final waste form for the Silo 3 waste would also have to meet the UTS standards for all of these constituents.

Alternatively, a delisting petition could be prepared per 40 CFR 260.22 "Petitions to Exclude a Waste Produced at a Particular Facility," for the K-65 treated waste glass. The potential delisting limits (Table II, Columns C and D) required for the K-65 waste glass are calculated as follows:

- $\quad$ assume 1.8 million gallons waste x $50 \%$ waste loading x $10 \mathrm{yr}$ treatment $=180,000$ gallons disposed $/ y r[7]$ 
This allows a Dilution/Attenuation Factor (DAF) of 100 and generates the Delisting Limits given in Table II, Column C, assuming a 10 year treatment period. If a 5 year treatment time is used, the volume of glass produced per year is increased, and the DAF is reduced to 80 - yielding the delisting limits in Table II, Column D. If the waste form is delisted it will have to meet the delisting limits for all the constituents given in Table II, including fluoride and cyanide. Delisting of the K-65 waste glass product is attractive because it raises the Pb TCLP release limit from $0.75 \mathrm{mg} / \mathrm{L}$ to 1.2 or $1.5 \mathrm{mg} / \mathrm{L}$ depending on the treatment times.

Table II. Final 1998 EPA TCLP Land Disposal Restrictions, Phase IV [10].

\begin{tabular}{|c|c|c|c|c|}
\hline & Column A & Column B & Column C & Column D \\
\hline Element & $\begin{array}{c}\text { Characteristically } \\
\text { Hazardous TCLP } \\
\text { Limits (mg/L) } \\
{[8]}\end{array}$ & $\begin{array}{c}\text { FinaPhase IV } \\
\text { TCLP UTS } \\
\text { Limits } \\
(\mathrm{mg} / \mathrm{L}) \\
{[10]}\end{array}$ & $\begin{array}{c}\text { Delisting Limit } \\
\text { TCLP, mg/L } \\
\text { 10 Year } \\
\text { Treatment } \\
\text { DAF }=100[7]\end{array}$ & $\begin{array}{c}\text { Delisting Limit } \\
\text { TCLP, mg/L } \\
5 \text { Year } \\
\text { Treatment } \\
\text { DAF }=80[7]\end{array}$ \\
\hline$\overline{A g}$ & 5 & 0.14 & 20 & 16 \\
\hline As & 5 & 5.0 & 5.0 & 4.0 \\
\hline $\mathrm{Ba}$ & 100 & 21 & 200 & 160 \\
\hline $\mathrm{Be}$ & --- & 1.22 & 0.40 & 0.32 \\
\hline $\mathrm{Cd}$ & 1 & 0.11 & $0.50 r$ & 0.40 \\
\hline $\mathrm{Cr}$ & 5 & 0.60 & 10 & 18.0 \\
\hline $\mathrm{Hg}$ & 0.2 & 0.025 & 0.20 & 0.16 \\
\hline $\mathrm{Ni}$ & --- & 11 & 10 & 8.0 \\
\hline $\mathrm{Pb}$ & 5 & 0.75 & 1.5 & 1.2 \\
\hline $\mathrm{Sb}$ & -- & 1.15 & 0.60 & 0.48 \\
\hline $\mathrm{Se}$ & 1 & $5.7^{*}$ & 5.0 & 4.0 \\
\hline $\mathrm{Tl}$ & --- & 0.20 & 0.20 & 0.16 \\
\hline $\mathrm{V} * *$ & --- & 1.6 & 20 & 16 \\
\hline $\mathrm{Zn} * *$ & -- & 4.3 & --- & -- \\
\hline F & --- & 400 & 400 & 320 \\
\hline $\mathrm{CN}$ & -- & $\begin{array}{c}30 \\
\text { (amenable) }\end{array}$ & $\begin{array}{c}590 \text { total } \\
\mathrm{mg} / \mathrm{kg}\end{array}$ & $\begin{array}{c}590 \text { total } \\
\mathrm{mg} / \mathrm{kg}\end{array}$ \\
\hline
\end{tabular}

* Se must be treated to the characteristic limit $(1.0 \mathrm{mg} / \mathrm{L})$ to be nonhazardous, although it may be land disposedas a hazardous waste if $<5.7 \mathrm{mg} / \mathrm{L}$ TCLP

** $\mathrm{V}$ and $\mathrm{Zn}$ are not underlying hazardous constituents

This would necessitate less reformulation of the Fernald waste glass product than the alternative of meeting the Phase IV UTS limits.

\section{EXPERIMENTAL}

Due to the potential for stable and/or metastable phase separation in the MO$\mathrm{SiO}_{2}-\mathrm{B}_{2} \mathrm{O}_{3}$ glass forming systems, this study concentrated on methods to lower 
the melt temperature of SLS glasses. In the SLS glass forming system $\mathrm{PbO}, \mathrm{MgO}$ and $\mathrm{BaO}$ can all substitute for $\mathrm{CaO}$ in the glass structure without separation of a second phase.

Only one SLS glass was formulated by SRTC as an initial scouting test for developing a low melting SLS glass. The glass had a targeted waste loading of $\sim 82 \%$ based on an the average Silo 1 and Silo 2 waste composition given in Table I. Lithia $\left(\mathrm{Li}_{2} \mathrm{O}\right)$ was partially substituted for the $\mathrm{Na}_{2} \mathrm{O}$ so that about 8 wt $\% \mathrm{Li}_{2} \mathrm{O}$ and $8 \mathrm{wt} \% \mathrm{Na}_{2} \mathrm{O}$ were the only two additives. This surrogate waste glass composition melted at $1050^{\circ} \mathrm{C}$. The target and analyzed composition of this glass is given in Table III. The final waste loading in the as analyzed glass was $84 \%$.

The TCLP results for the SRTC glass formulation are given in Table IV and compared with published TCLP results of the raw K-65 waste and the glasses formulated by PNNL. The SRTC formulation melts $300^{\circ} \mathrm{C}$ lower than the PNNL formulation but is of equivalent durability and waste loading to the high temperature K-65 glass and more durable than the low melting VSL borosilicate glass. The PNNL, VSL and SRTC glasses all pass the EPA TCLP concentration limits before the Phase IV UTS limits went into effect, e.g. pre-August, 1998 (Table IV). The PNNL and SRTC glasses pass at or below the delisting limits while the VSL glasses do not." The SLLS glass formulations require further optimization based on the 1998 waste compositions in reference 4 (Table I) now that the final Phase IV UTS limits (Table II) have been adopted.

The glass attributes of the SRTC SLLS glass are compared to the glasses formulated for FEMP by PNNL and VSL in Table V.

Table III. SRTC Soda-Lithia-Lime-Silica (SLLS) Glass

\begin{tabular}{lcc}
\hline GLASS COMPONENT & $\begin{array}{c}\text { OXWE WT\% } \\
\text { Target }\end{array}$ & $\begin{array}{c}\text { OXIDE WT\% } \\
\text { As Analyzed }\end{array}$ \\
\hline $\mathrm{Al}_{2} \mathrm{O}_{3}$ & 3.14 & 4.32 \\
$\mathrm{BaO}$ & 5.35 & 4.95 \\
$\mathrm{CaO}$ & 1.27 & 1.44 \\
$\mathrm{Cr}_{2} \mathrm{O}_{3}$ & --- & 0.14 \\
$\mathrm{Fe}_{2} \mathrm{O}_{3}$ & 4.08 & 4.51 \\
$\mathrm{~K}_{2} \mathrm{O}$ & 0.76 & 0.73 \\
$\mathrm{Li}_{2} \mathrm{O}$ & 8.50 & 7.92 \\
$\mathrm{MgO}$ & 1.44 & 1.63 \\
$\mathrm{Na}_{2} \mathrm{O}$ & 10.88 & 9.85 \\
$\mathrm{NiO}$ & - & 0.09 \\
$\mathrm{P}_{2} \mathrm{O}_{5}$ & 0.68 & 0.96 \\
$\mathrm{PbO}^{\mathrm{SiO}}$ & 10.45 & 10.30 \\
$\mathrm{SUM}$ & 53.44 & 53.10 \\
& 99.99 & 100.03 \\
\hline
\end{tabular}


Table IV. Comparative EPA TCLP Testing for K-65 Waste and for K-65 Waste Glasses Formulated by PNNL, VSL, and SRTC

\begin{tabular}{|c|c|c|c|c|c|c|}
\hline $\begin{array}{l}\text { RCRA } \\
\text { Metal }\end{array}$ & $\begin{array}{c}1997 \\
\text { Proposed } \\
\text { UTS } \\
\text { Limits } \\
\\
(\mathrm{mg} / \mathrm{L}) \\
\end{array}$ & $\begin{array}{c}\text { Raw K-65 } \\
\text { Residue } \\
\\
{[1]} \\
(\mathrm{mg} / \mathrm{L})\end{array}$ & $\begin{array}{c}\text { PNNL-A } \\
\text { SLS } \\
\text { K-65 Waste } \\
\text { Glass } \\
{[2]} \\
(\mathrm{mg} / \mathrm{L}) \\
\end{array}$ & $\begin{array}{c}\text { VSL } \\
\text { Borosilicate } \\
\text { K-65 Waste } \\
\text { Glass } \\
{[2]} \\
(\mathrm{mg} / \mathrm{L}) \\
\end{array}$ & $\begin{array}{c}\text { SRTC } \\
\text { SLLS } \\
\text { K-65 Waste } \\
\text { Glass } \\
\text { Replicate A } \\
\text { (mg/L) } \\
\end{array}$ & $\begin{array}{c}\text { SRTC } \\
\text { SLLS } \\
\text { K-65 } \\
\text { Waste Glass } \\
\text { Replicate B } \\
\text { (mg/L) } \\
\end{array}$ \\
\hline $\mathrm{Ag}$ & 0.11 & $<0.1$ & $<0.01$ & --- & 0.026 & 0.020 \\
\hline As & 5.0 & $<1.0$ & $\begin{array}{c}0.004- \\
0.005\end{array}$ & -.. & $<0.002$ & $<0.002$ \\
\hline $\mathrm{Ba}$ & 21 & 0.76 & $0.69-0.87$ & --. & 2.62 & 2.73 \\
\hline $\mathrm{Cd}$ & 0.20 & 0.1 & $<0.005$ & --. & $<0.010$ & $<0.010$ \\
\hline $\mathrm{Cr}$ & 0.85 & $<0.2$ & $<0.01$ & -.- & $<0.04$ & $<0.04$ \\
\hline $\mathrm{Hg}$ & 0.025 & $<0.03$ & $<0.0002$ & -- & $<0.0096$ & $<0.0096$ \\
\hline $\mathrm{Ni}$ & 13.6 & 3.2 & -- & $\ldots$ & 0.062 & $<0.050$ \\
\hline $\mathrm{Pb}$ & 0.75 & 630 & $0.81-1.2$ & $1.9-2.76$ & 1.272 & 1.619 \\
\hline $\mathrm{Se}$ & 5.7 & $<0.1$ & $<0.002$ & $\ldots$ & 0.158 & 0.297 \\
\hline
\end{tabular}

Table V. Comparison of Attributes of Glasses Formulated for FEMP K-65 Silo Wastes.

\begin{tabular}{|c|c|c|c|c|}
\hline GLASS ATTRIBUTES & $\begin{array}{c}\text { SRTC } \\
\text { Formulation }\end{array}$ & $\begin{array}{c}\text { PNNL } \\
\text { Formulations } \\
\end{array}$ & $\begin{array}{c}\text { PNNL } \\
\text { Formulations } \\
\end{array}$ & $\begin{array}{c}\text { VSL } \\
\text { Formulations } \\
\end{array}$ \\
\hline $\begin{array}{l}\text { Glass Forming } \\
\text { System }\end{array}$ & $\begin{array}{l}\text { Soda-Lithia- } \\
\text { Lime-Silica }\end{array}$ & $\begin{array}{l}\text { Soda-Lime- } \\
\text { Silica and } \\
\text { Borosilicate }\end{array}$ & Borosilicate & Borosilicate \\
\hline $\begin{array}{l}\text { Phase Separation } \\
\text { Melt Temperature } \\
\left({ }^{\circ} \mathrm{C}\right)\end{array}$ & $\begin{array}{c}\text { No Potential } \\
1050\end{array}$ & $\begin{array}{c}\text { No Potential } \\
1289-1595\end{array}$ & $\begin{array}{c}\text { Observed } \\
1150\end{array}$ & $\begin{array}{l}\text { Potential } \\
1000-1050\end{array}$ \\
\hline Waste Loading (\%) & 84 & $80-84$ & $<50$ & $60-74$ \\
\hline $\begin{array}{l}\text { Volume Reduction } \\
(\%)\end{array}$ & $\sim 68$ & $55-68$ & $\begin{array}{c}\text { Not } \\
\text { Determined }\end{array}$ & $\begin{array}{c}\text { Not } \\
\text { Determined }\end{array}$ \\
\hline Density $\left(\mathrm{g} / \mathrm{cm}^{3}\right)$ & 2.86 & 3.1 & $\begin{array}{c}\text { Not } \\
\text { Determined }\end{array}$ & $\begin{array}{c}\text { Not } \\
\text { Determined }\end{array}$ \\
\hline $\begin{array}{l}\text { Inconel }{ }^{\circledR} 690 \\
\text { Compatible }\end{array}$ & Demonstrated & $\begin{array}{c}\text { Not } \\
\text { Determined }\end{array}$ & $\begin{array}{c}\text { Not } \\
\text { Determined }\end{array}$ & $\begin{array}{c}\text { Not } \\
\text { Determined }\end{array}$ \\
\hline
\end{tabular}




\section{CONCLUSIONS}

Glasses for the FEMP K-65 silo wastes should be formulated in the Soda-LimeLithia-Silica (SLLS) system or the to avoid problematic phase separation known to occur in borosilicate glass forming systems, e.g. the $\mathrm{MO}-\mathrm{B}_{2} \mathrm{O}_{3}-\mathrm{SiO}_{2}$ glass forming systems where $\mathrm{MO}=\mathrm{CaO}, \mathrm{MgO}, \mathrm{BaO}$, and $\mathrm{PbO}$. The K-65 wastes contain all of these MO oxides which makes phase separation likely. Phase separation is known to compromise glass durability.

Glasses for the FEMP K-65 silo wastes should be formulated to melt at the lowest temperatures reasonably achievable to minimize volatilization of radioactive radon and hazardous species such as lead, arsenic, selenium, and chromium. The one scouting test performed in this study indicates that acceptable low melting SLS glasses can be formulated which melt at temperatures as low as $1050^{\circ} \mathrm{C}$. High waste loading, e.g. $84 \mathrm{wt} \%$, can still be maintained by the addition of only two glass forming additives, $\mathrm{Li}_{2} \mathrm{O}$ and $\mathrm{Na}_{2} \mathrm{O}$ using the SRTC Lithia Additive Stabilization Process (LAMP ${ }^{\mathrm{TM}}$ ). ${ }^{*}$ Further optimization of SLLS glasses using the LAMP technology needs to be investigated for FEMP.

The SRTC SLLS glass passes the Environmental Protection Agency (EPA) Toxic Characteristic Leach Procedure (TCLP) for all the hazardous constituents of concern under the pre August, 1998 regulations and at the delisting limits. The SLLS glass is as durable as the high melting SLS glasses formulated by Pacific Northwest Laboratory (PNNL) and is more durable than the borosilicate glasses formulated by the Vitreous State Laboratory (VSL) for the K-65 wastes.

SRTC successes in late 1997 with co-vitrification of two highly variable mixed wastes at the Oak Ridge Reservation (ORR) into SLLS glass indicate that high sulfate and high organic containing (including wood chips) wastes can successfully be vitrified [11] using the LAMP ${ }^{\mathrm{TM}}$ technology. These vitrification successes were completed in a field scale Transportable Vitrification System (TVS) at the ORR.

\section{ACKNOWLEDGMENTS}

This paper was prepared in connection with work done under Contract No. DEAC09-96SR18500 with the U.S. Department of Energy. The current study was funded by the Department of Energy, EM-50, Mixed Waste Focus Area.

\footnotetext{
* Patent pending.
} 


\section{REFERENCES}

1. D.S. Janke, C.C. Chapman, and R.A. Vogel, "Results of Vitrifying Fernald K-65 Residue," Nuclear Waste Management, IV, Ceramic Transactions, V.23, G.G. Wicks, D.F. Bickford and L. Bunnel (Eds.), American Ceramic Society, Westerville, OH, 53-61 (1991).

2. R.A. Merrill, and D.S. Janke, "Results of Vitrifying Fernald OU-4 Wastes,” Waste Management ‘93, 1369-1374 (1993).

3. U.S. DOE Report FEMP-O4RT-6 Final (November 3, 1993).

4. Fluor Daniel Fernald Acquisitions, "Silos 1 and 2 Proof of Principle Testing," World Wide Web.Fernald.gov (February 11, 1998).

5. M.B. Volf, Chemical Approach to Glass, Glass Science and Technology, V. 7, Elsevier, New York, 594p. (1984).

6. D.W. Johnson and F.A. Hummel, "Phase Equilibria and Liquid Immiscibility in the System PbO- $\mathrm{B}_{2} \mathrm{O}_{3}-\mathrm{SiO}_{2}$," J. Am. Ceram. Soc., 51[4], 197-201 (1968).

7. C.M. Jantzen and J.B. Pickett, "Vitrification of Simulated Fernald K-65 Silo Waste at Low Temperature," U.S. DOE Report WSRC-TR-0061, Westinghouse Savannah River Company, Aiken, SC (January 14, 1998).

8. Environmental Protection Agency Code of Regulations 40-CFR-261.24(b).

9. Land Disposal Restrictions, Phase IV - Proposed Rule, Federal Register, 60 FR 43654, p. 43683-4 (August 22, 1995) and Federal Register, 'Land Disposal Restrictions-Phase IV: Second Supplemental Proposal on Treatment Standards for Metal Wastes, Mineral Processing and Bevill Exclusion Issues, and the Use of Hazardous Wastes as Fill, Supplemental Proposed Rule," 62 FR 26041 (May 12, 1997).

10. Environmental Protection Agency, "Land Disposal Restrictions - Phase IV: Final Rule Promulgating Treatment Standards for Metal Wastes and Mineral Processing Wastes, Mineral Processing and Bevill Exclusion Issues; Treatment Standards for Hazardous Soils, and Exclusion of Recycled Wood Preserving Wastewaters; Final Rule," 62 FR 62079 (May 26, 1998).

11. A. D. Cozzi, C.M. Jantzen, K.G. Brown and C. Cicero-Herman, "Process Control for Simultaneous Vitrification of Two Mixed Waste Streams in the Transportable Vitrification System (TVS)," this proceedings. 